\title{
Clonal Propagation of Flacourtia indica for Ensuring Quality Planting Materials and Sustainable Supply of Edible Fruits
}

\author{
Md. Alamgir Kabir (Corresponding author) \\ Department of Agroforestry, Patuakhali Science and Technology University \\ Dumki, Patuakhali-8602, Bangladesh \\ Tel.: +88 04427-56014/468 Fax: +88-0027-56009 E-mail:alamgirmk@gmail.com \\ Md. Hasan Mehedi Khan \\ Department of Agroforestry, Patuakhali Science and Technology University \\ Dumki, Patuakhali-8602, Bangladesh \\ Tel.: +88 04427-56014/296 Fax: +88-0027-56009 E-mail: ksawrav@gmail.com \\ Md. Masudur Rahman \\ Department of Agroforestry, Patuakhali Science and Technology University \\ Dumki, Patuakhali-8602, Bangladesh
}

Tel.: +88 04427-56014/296 Fax: +88-0027-56009 E-mail: masudaf2007@yahoo.com

\begin{abstract}
A.T.M. Rabiul Alam
Department of Agroforestry, Patuakhali Science and Technology University

Dumki, Patuakhali-8602, Bangladesh

Tel.: +88 04427-56014/296 Fax: +88-0027-56009 E-mail: tisam_a@yahoo.com
\end{abstract}

S.M. Hemayet Jahan

Department of Entomology, Patuakhali Science and Technology University

Dumki, Patuakhali-8602, Bangladesh

Tel.: +88 04427-56014/413 Fax: +88-0027-56009 E-mail: hemayet_pstu@yahoo.com

\author{
A.K.M. Mostafa Zaman \\ Department of Geo-information Science and Earth Observation \\ Patuakhali Science and Technology University \\ Dumki, Patuakhali-8602, Bangladesh \\ Tel.: +88 04427-56014/240 Fax: +88-0027-56009 E-mail: mostafazamanpstu@gmail.com \\ Muhammad Zahid Al Mamun \\ Central Laboratory, Patuakhali Science and Technology University \\ Dumki, Patuakhali-8602, Bangladesh \\ Tel.: +88 04427-56014/392 Fax: +88-0027-56009 E-mail: zampstu@yahoo.com
}

(Received: Apr 22, 2016; Reviewed: Nov 16, 2016; Accepted: Apr 20, 2017)

\section{DOI: http://dx.doi.org/10.20956/ijas.v5i1.1169}

\begin{abstract}
The present study was carried out at the Agriculture research field, Patuakhali Science And Technology University(PSTU), Patuakhali, from March, 2015 to April, 2016 to explore the domestication potential and to evaluate the rooting performance of Flacourtia indica (katabohori), a wild fruit species in Bangladesh, through clonal propagation by stem cutting under 3 different doses of rooting hormone IBA (Indole Buetaric Acid) and planted in the perforated plastic tray filled with coarse sand and gravel placed in the non-mist propagator.
\end{abstract}


The experiment was laid out following a Randomized Complete Block Design (RCBD) with 4 treatments and 4 replications (blocks). The treatments were $\mathrm{T}_{0}=$ control, $\mathrm{T}_{1}=0.2 \% \mathrm{IBA}$, $\mathrm{T}_{2}=0.4 \%$ IBA, $\mathrm{T}_{3}=0.8 \%$ IBA. The rooting ability of cuttings was significantly influenced by the application of IBA. The results showed that the highest rooting percentage (100) and maximum root number (8) of Flacourtia indica stem cuttings were obtained from the cuttings treated with $0.4 \%$ IBA followed by $0.2 \%$ IBA where as the longest root length $(8.998 \mathrm{~cm})$ was recorded with $0.2 \%$ IBA followed by $0.4 \%$ IBA. Survival percentage of the cutlings (the rooted cuttings) after 3 months of transferring them into poly bags was also significantly enhanced by exogenous rooting hormone (IBA) application. The highest survival percentage $(84.5 \%)$ was for the cuttings treated with $0.4 \%$ IBA followed by $0.2 \%$ IBA $(71 \%)$. The similar trend was also observed for average cutling height and number of leaf. Findings of the present study reveal that the plant species is highly amenable for clonal propagation by stem cuttings using low-cost non-mist propagator. Considering both rooting percentage and root number, $0.4 \%$ IBA treatment of stem cuttings may be recommended for mass production of quality planting stocks for the domestication of the species in homestead agroforestry or in fruit orchards to provide edible fruit to rural poor people of natural disaster vulnerable Bangladesh.

Keywords: Flacourtia indica; IBA; clonal propagation; Non-mist propagator

\section{Introduction}

People of Bangladesh are generally poorly nourished despite substantial increase of food production in the country over past few decades. Most people suffer from malnutrition and resultant diseases. Ceaseless effort is therefore needed to improve the nutritional status and to increase food security, particularly for the rural poor (FAO, 1992). Wild fruit trees offer vital insurance against malnutrition or famine during the seasonal food shortage and/or emergencies such as cyclone, floods, drought etc. though forest originated wild fruits are not consumed in greater quantities compared to main food staples. Wild fruits add variations in diets improve the palatability of staple foods and provide essential vitamins, minerals, proteins, carbohydrates and fats (Hossain et al., 2011).

Although the exact figure of the wild fruit species in the country is not known, Das (1987) compiled a list of sixty wild ed- ible fruit species from the forest areas of Bangladesh. Flacourtia indica (Burm. f.) Merr. commonly known as 'Baichi' or 'Katai', Synonymous to Flacourtia ramontchi L'Herit. (Family-Flacourtiaceae) is one of the important endangered fruit and medicinal plant species of Bangladesh. This is a bushy shrub or tree (Fig. 1) with a spiny trunk and branches. In shrub form it grows up to 25 feet $(7.6 \mathrm{~m})$ and as a tree it reaches a maximum height around 50 feet $(15 \mathrm{~m})$. The drooping branches bear oval leaves. Fruit is a small, red, fleshy, round berry. It turns a dark reddish-black when mature, and contains 4 to 10 brown, flattened, wrinkled seeds. The pulp is yellow or white and sweet with an acidic tang. It is eaten raw or made in to jelly or jam. It can be fermented to make wine. F. indica fruits are contained substantial amount of glucose and fructose as the main components. The main constitute of the polysaccharides in all the fruits was glucose and dietary fibre contents of the dry 
fruit was 29 to $79 \%$ but that fruit has by far the best combination of low free sugars and high dietary fibre (Nahar et al., 1990).

Flacourtia indica is an indigenous medicinal plant of Bangladesh (Figure 1) and India and it has been reported as an answer for the treatment of a variety of diseases and functional disorder. Fruits are used as appetizing, diuretic, and digestive, in jaundice and enlarged spleen. Barks are used for the treatment of intermittent fever also believed to be effective for arthritis. Roots are used in nephritic colic and gum is used in cholera (Kirtikar and Basu, 1998, Nazneen et $a l .$, 2002). The leaves and roots are used in herbal medicine for treatment of snakebite. Most parts of the plant are used for cough, pneumonia, and bacterial throat infection. It has also been used for diarrhea. There are different methods of domestication of plant species including various stages of development as mentioned by Booth and Turnball
(1994). Among the stages, regeneration or propagation of the species play vital roles in the domestication process. Plants can be regenerated through seed germination or vegetative means like budding, grafting, stem cuttings or tissue culture. However, very little is known about the regeneration of the F. indica. The seeds are dispersed by birds. To a limited extent the species is propagated from coppice. The species can be propagated from seed but little is known about germination techniques. Moreover, the information about the artificial regeneration of the species through vegetative propagation by stem cutting is very scarce and therefore extensive research in this aspect is needed for domestication considering its role in rural livelihood of Bangladesh. So, present study attempted to investigate the rooting ability of small leafy branch cuttings in low cost farmers' friendly non-mist propagator with or without rooting hormone IBA.

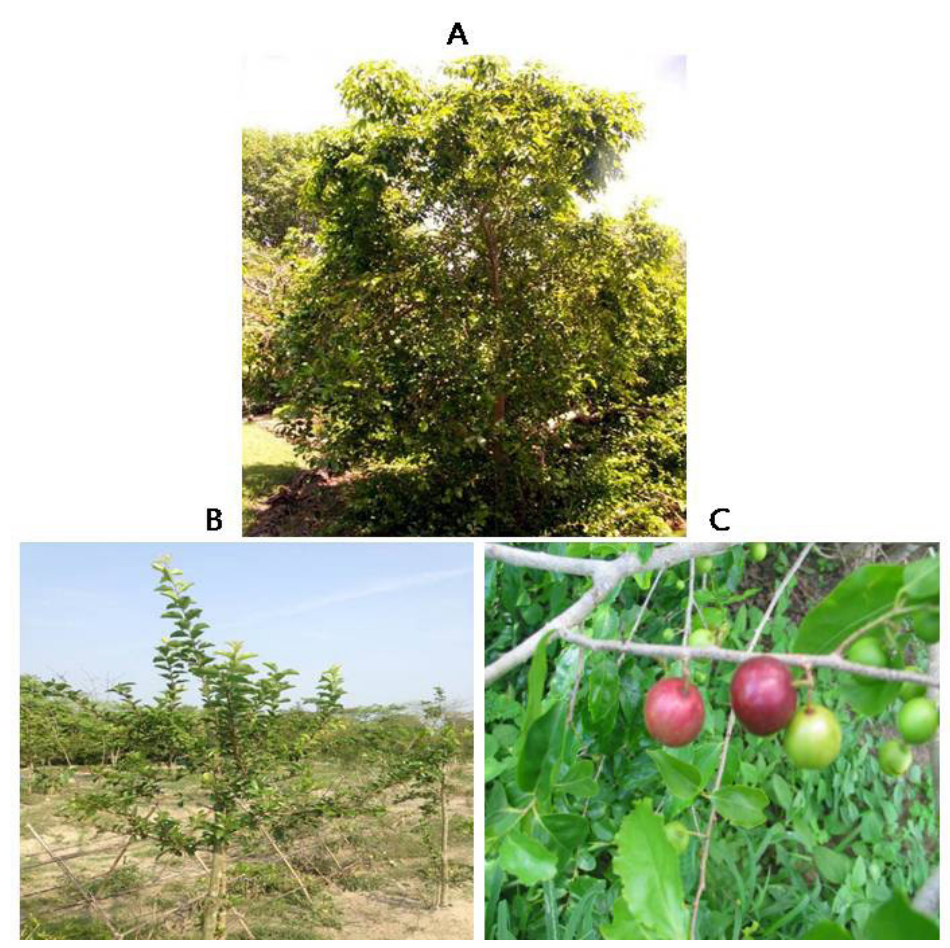

Figure. 1. Full grown tree (a), 2 years old seedling at germplasm centre and ripe fruits of F. indica 


\section{Materials and methods}

\subsection{Study location and climate}

The study was conducted from at the Agriculture research field of Patuakhali Science and Technology University campus (lies between $21^{\circ} 48^{\prime}$ and $22^{\circ} 36^{\prime}$ north latitudes and between $90^{\circ} 08^{\prime}$ and $90^{\circ} 41^{\prime}$ ' east longitudes) Bangladesh (Figure 2) which enjoys typical tropical climate characterized by hot humid summer and cool dry winter. The average temperature ranged between $14.3^{\circ}$ to $27.4^{\circ} \mathrm{C}$ in winter and between $24.3^{\circ}$ to $33.6^{\circ} \mathrm{C}$ during summer from 2010 to 2014 (Figure 3). The average annual rainfall was $2657 \mathrm{~mm}$ and varied from $1877 \mathrm{~mm}$ to 3120 $\mathrm{mm}$ (Figure 3) and rainfall usually takes place between June and September. The day length varies from $10 \mathrm{~h} 45 \mathrm{~min}$ in December to $13 \mathrm{~h} 25 \mathrm{~min}$ in June. Relative humidity is minimum (64\%) in February and maximum $(95 \%)$ in June to September.

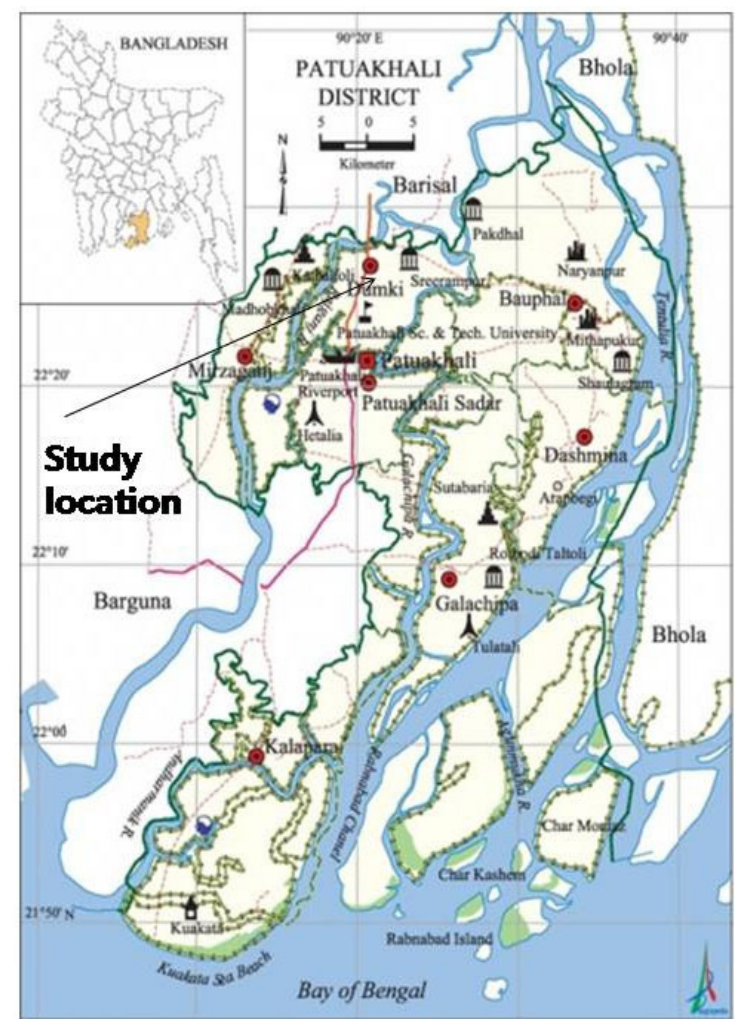

Figure 2. A geographical location of PSTU at Dumki Upazila

\subsection{Preparation of stem cuttings and set-} ting up the experiment

The study on vegetative propagation was carried out in a low cost non-mist propagator (Figure 3 ). The non-mist propagator was constructed following the design described by Leakey et al. (1990) modified by Kamaluddin (1996) and was covered with sheet of transparent polythene such that the base was completely watertight and the lid was also airtight. The polythene base of the propagator was covered with a 10 $\mathrm{cm}$ thick layer of moist coarse sand mixed with successive layers of fine gravels and small stones. This layer supported rooting media kept in perforated plastic trays. Juvenile shoots of $F$. indica were collected from 2-years old stock plants raised in the Germplasm Centre of PSTU to get quality propagules. Two-node stem cuttings were prepared keeping two leaves intact without any trimming (considering smaller leaf area of $F$. indica) and then immersed briefly in a solution of fungicide Diathane M45 (Rohm and Co Ltd, France; $2 \mathrm{~g} / \mathrm{L}$ in water) to avoid fungal infection. The cuttings were then rinsed and kept under shade for 10 minutes in open air for drying. As growth regulators are organic compounds that needed in the least amount which can support, inhibit, and may alter physiological processes of plants (Ulfa et al., 2013), stem cuttings were then treated with $0 \%$ (control), $0.2 \%, 0.4 \%$ and 0.8\% IBA (Indole 3-Butyric Acid) solutions by dipping the cutting base into IBA solution to test effect of IBA on rooting ability and finally treated cuttings were planted into perforated plastic trays (12 cm depth) filled with coarse sand (Sylhet sand) mixed with fine 
A

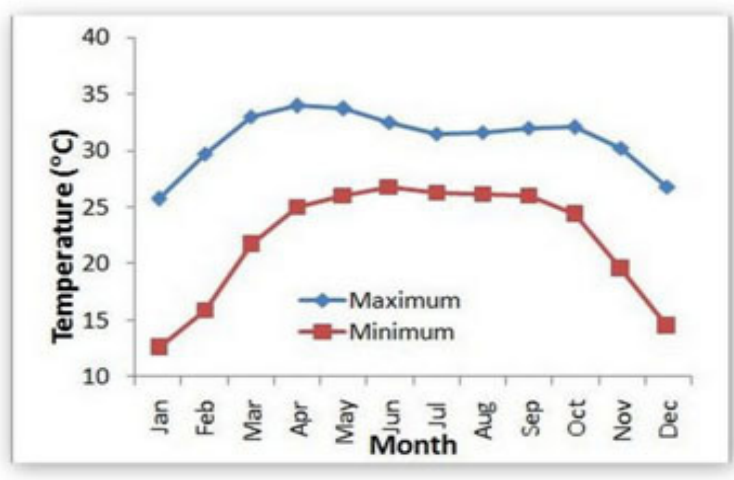

B

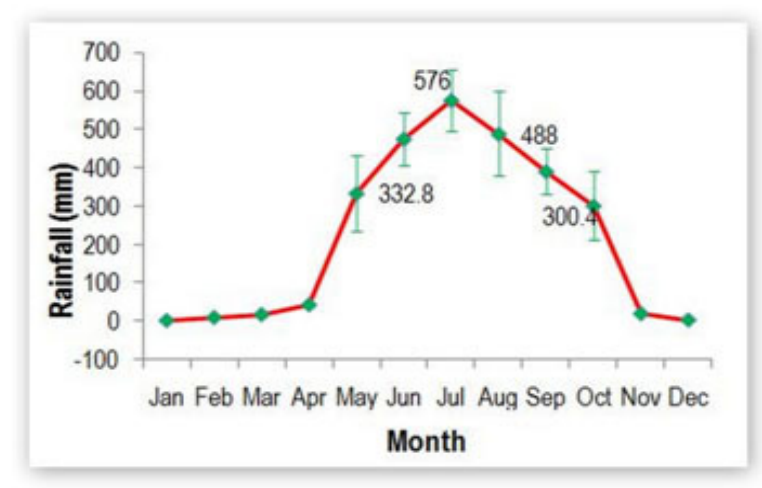

Figure 3. Temperature and rainfall at Patuakhali region from data of conjugative 5 years (2010-2014) (Source: Khepupara meteorological station).

gravel following a Randomized Complete Block Design (RCBD). A total of 160 cuttings were placed under four different treatments with four replications per treatment. Ten cuttings treated with same concentration of IBA were placed in each plastic tray and each tray served as an experimental plot. Thus the number of replication of cuttings per treatment was 40 . The cuttings were watered once only just after setting inside the propagator.

\subsection{Propagator environment, aftercare and transplanting}

The propagator was kept under bamboo made shed to avoid excessive heat accumulation. The propagator was opened briefly in the morning and in the late afternoon to facilitate gaseous exchange. Whenever the propagator lid was opened for observation, a fine jet of water spraying was applied to cuttings to maintain a low vapor pressure deficit inside the propagator. This resulted in a permanently humid environment throughout the propagation period (around $85 \%$ relative humidity).
The assessments of rooting success were carried out weekly after the first two weeks of cutting placement in the propagator. A cutting was considered as rooted when it had at least one root exceeding $1 \mathrm{~cm}$ long. The rooting of cuttings in the propagator completed within six weeks after putting the cuttings into the rooting media in propagator.

After six weeks in the rooting medium, the rooted cuttings in the propagator were to weaned before transferring them in to poly bags, particularly towards the end of rooting period during root lignifications. For weaning, the propagator was kept open at night for three days and then at day and night for another three days. The weaned rooted cuttings were then transferred into poly bags filled with soil and decomposed cow dung at a ratio of $3: 1$. Before planting into the poly bags, rooted cuttings were measured for rooting percentage, number of roots developed per cutting and the length of longest root. 


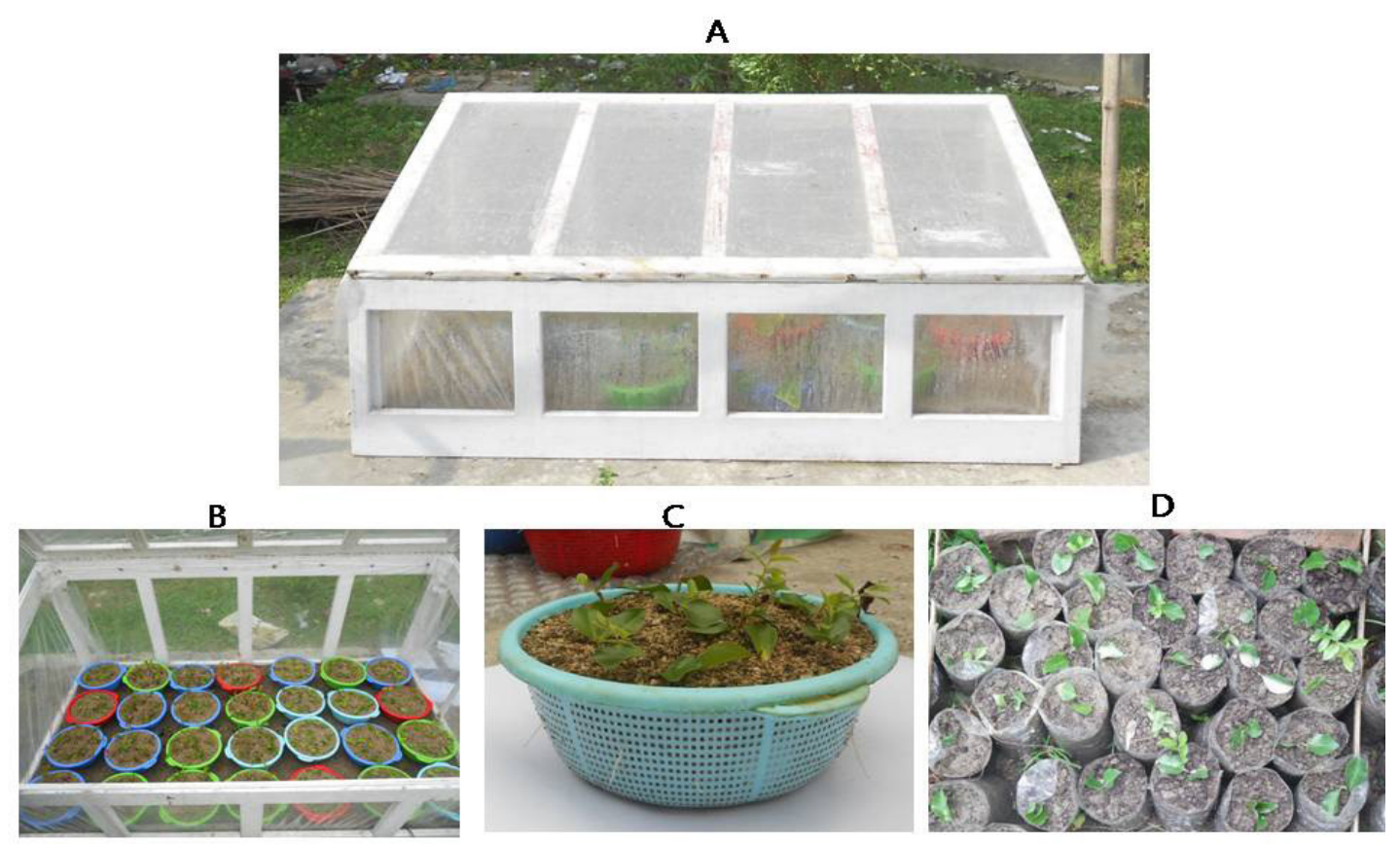

Figure 3. Non-mist wooden frame polythene propagator (a), Inside of propagator after setting of experiment (b), Plastic tray showing rooted cuttings(c), Rooted cuttings after transferring into growing media filled polyethylene bags

\subsection{Data analysis}

Mean values for root number, root length and root diameter were calculated on experimental plot basis. All data were analyzed through computer based statistical program MSTAT-C (Michigan State University, East Lansing, MI, USA) following the basic principles, as outlined by Gomez and Gomez (1984). Significant effects of treatments were determined by analysis of variance (ANOVA) and treatment means were compared at 5\% level of significance by Duncan's Multiple Range Test (DMRT). Microsoft EXCEL package (Microsoft Corporation, Pullman, WA, USA) were used for correlation and regression analysis. Rooting percentage was calculated and values were adjusted accordingly using arc sign transformation formula before putting the data into Analysis of Variance since the percentages of cuttings rooted were distributed between the range of 30 to 100 and proportions were based on equal denominator.

\section{Results and Discussion}

\subsection{Rooting ability}

Rooting percentage of $F$. indica cuttings was significantly enhanced by exogenous rooting hormone (IBA) (Figure 4 and $5)$. The highest rooting percentage $(80.5 \%)$ was obtained from the cuttings treated with $0.4 \%$ IBA solution followed by the cuttings treated with $0.2 \%$ IBA $(76.25 \%)$. The lowest rooting percentage $(62.25 \%)$ was in cuttings without IBA treatment (control).

Applied rooting hormone IBA is known to intensify the rooting percentage of cuttings as explained by many authors. Hossain et al. (2011) reported that the exogenous auxin (0.4\%IBA) significantly ( $p$ 0.05) enhances the rooting percentage of cuttings of Flacourtia jangomas. Hossain et al. (2002) also reported the same for cuttings 


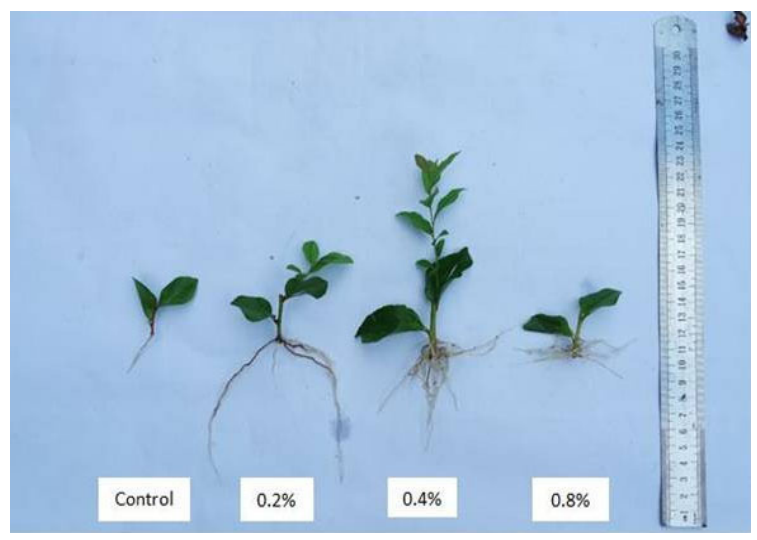

Figure 4. Rooting ability of cuttings of F. indica under various IBA treatments

of jackfruit. Similar results were reported by Abdullah et al. (2005) for Baccaurea sapida Muell. Arg. mature stem cuttings. The effect of IBA on the rooting of stem cuttings of Platanus acerifolia of different diameters was studied in Brazil by Dias et al. (1999) and found that the cuttings treated with $6000 \mathrm{ppm}$ IBA was better rooted than the controlled cuttings.

The effect of IBA on the rooting of tachi-brancho (Sclerolobium paniculatum) cuttings was investigated by Rosa et al. (1997) and observed that the cuttings treated with 4000ppm IBA were rooted best and the cuttings without treatment was rooted worst. Kamaluddin et al. (1996) recorded significant increases both in percentage rooting and number of roots with the application of IBA for Artocarpus heterophyllus. Again Kamaluddin et al. (1998) found that applied auxin significantly increased rooting ability of Chickrassia velutina cuttings.

\subsection{Root number}

Root number of cuttings was significantly enhanced due to the effect of applied IBA (Figure 6). The highest number of root (7.50) was developed in $0.4 \%$ IBA

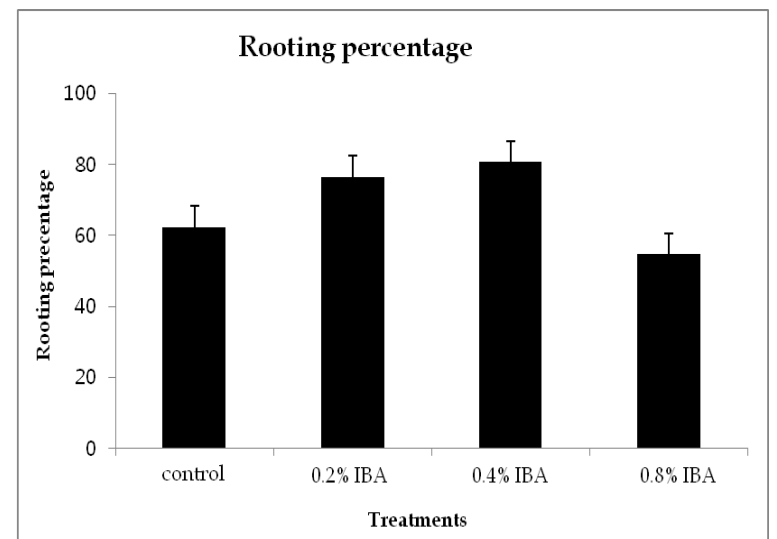

Figure 5. Rooting percentages of $F$. indica stem cuttings under different IBA concentrations

treated cuttings and lowest (2.50) was in cuttings without IBA treatment. The findings of several authors supported the result of the present study that enhanced number of roots developed due to the IBA treatment.

For instance, Hossain et al. (2002) mentioned that exogenous auxin ( $0.4 \%$ IBA) significantly ( $p$ 0.05) increased the root number of cutting of jackfruit. Abdullah et al. (2005) reported the highest root number in the cutting of Baccaurea sapida Muell. Arg. treated with $0.8 \%$ IBA solution. Dias et al. (1999) reported the highest number of root developed in the cutting of $P$. acerifolia treated with 6000ppm IBA 120 days after setting the cutting in the green house. The number of roots increased also with increasing IBA concentration for Neem (Azadirachta indica) cuttings treated with $0.2 \%$ or $0.4 \%$ IBA (Kamaluddin and Ali, 1996). Again Kamaluddin et al. (1996) recorded significant increases both in percentage rooting and number of roots with the application of IBA for Artocarpus heterophyllus. Again Kamaluddin et al. (1998) found that applied auxin significantly increased rooting ability of Chickrassia velutina cuttings. 


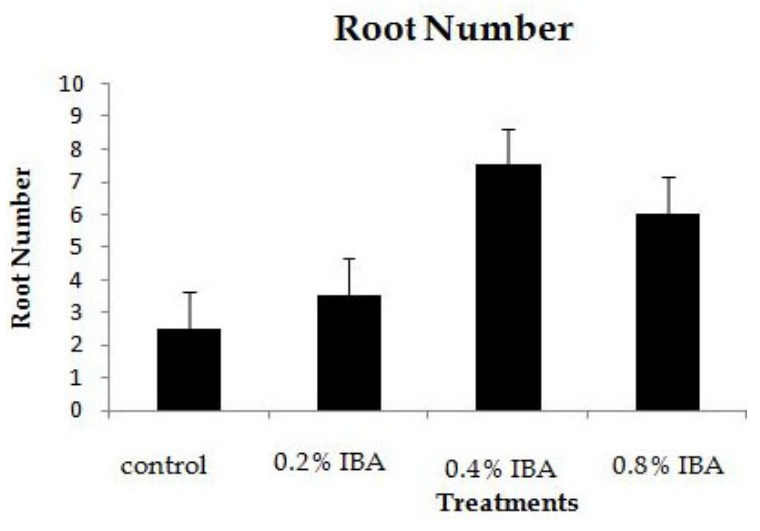

Figure 6. Root numbers of F. indica cuttings developed under various IBA concentrations after six weeks from establishing the cuttings

\subsection{Root length}

Root length was significantly influenced with the increasing IBA concentration (Figure 7 and 8). The longest root (8.99 $\mathrm{cm}$ ) was found in cuttings rooted with $0.2 \%$ IBA, whereas the shortest root was recorded from the cutting without IBA treatment. Similar result was reported by Abdullah et al. (2005) for Baccaurea sapida. It is evident from the present study that the cutting of $F$. indica rooted well even without any IBA treatment (50\%). However, the rooting ability of cutting in respect to rooting percentage, root number and longest root length was significantly enhanced with the applications of $0.2 \%$ to $0.4 \%$ IBA solution. Applied rooting hormone (IBA) increased rooting ability of cutting was reported by many authors including Hossain (1999), Hosaain et al. (2002), Hossain et al. (2004), Abdullah et al. (2005), Dias et al. (1999), Rosa et al. (1997), Kamaluddin et al. (1996), Kamaluddin and Ali (1996) and Kamaluddin et al. (1998) Hosaain et al. (2011).

Applied auxin is known to intensify root-forming process in cutting for instance, polysaccharide hydrolysis is activated under the influence of applied IBA, as a result the contents of psychologically active sugar increases providing materials for meristamatic tissues and later for root primordia and roots. Hassig (1983) examined the function of endogenous root forming components of plants, which had auxin components and non-auxin components. He demonstrated the auxin components was required for development of callus in which root primordia initiated, but for subsequent primordial development both auxin and non-auxin components were needed. It may be possible that in cutting with optimum amount of endogenous auxin content and increasing of root number reflected the effect of applied auxin.

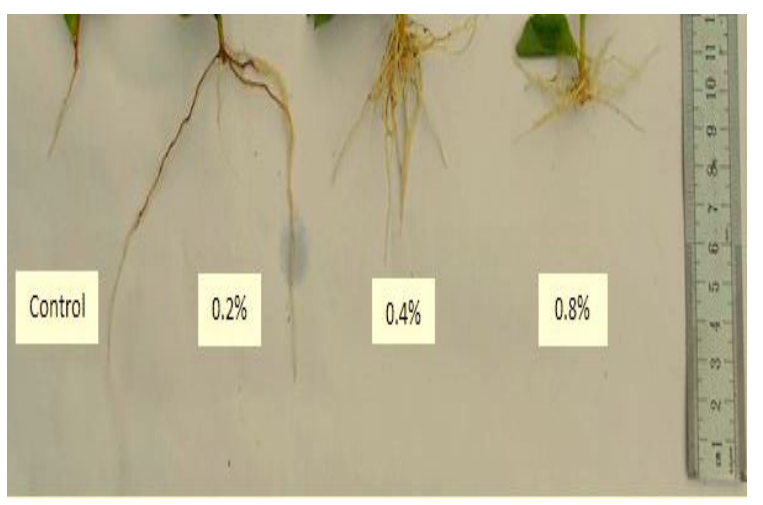

Figure 7. Longest root length recorded for different concentrations of IBA

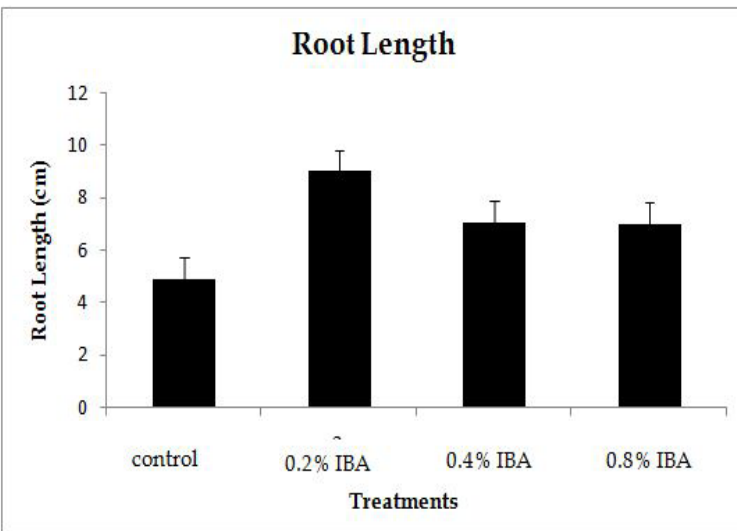

Figure 8. Root lengths of F. indica cuttings developed under various IBA concentrations after six weeks from establishing the cuttings 


\subsection{Steckling capacity}

Survival percentage of the cutlings (the rooted cuttings) significantly enhanced by exogenous rooting hormone (IBA) application (Figure 9). The highest survival percentage $(84.5 \%)$ was for the cuttings treated with $0.4 \%$ IBA followed by $0.2 \%$ IBA (71\%). The result is in accordance with the result for Flacourtia jangomas by Hossain et al. (2011) applying rooting hormone IBA using similar type of non-mist plant propagator.

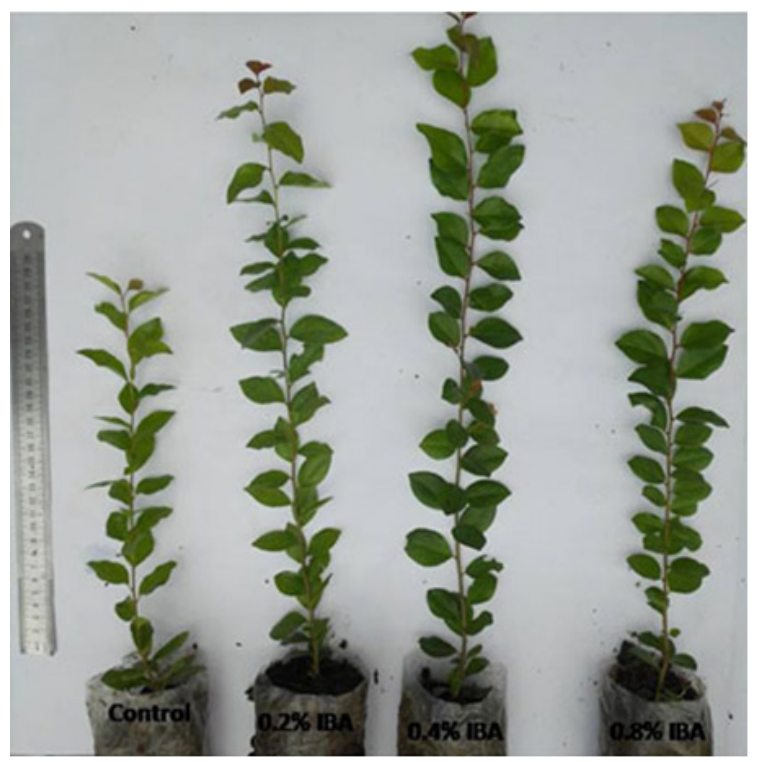

Figure 9. Growth performance of $F$. indica cutlings rooted due to IBA treatment three months after transferring into poly bags

\subsection{Cutling growth performance and leaf} number

Average height of cutlings was significantly increased by application of exogenous rooting hormone IBA (Table 1). Hossain et al. (2011) got similar result on cutling height applying IBA for Flacourtia jangomas stem cuttings.

Leaf number of cutlings was also significantly increased with the increase of applied IBA concentration (Table 1). This result on leaf number is in accordance with the findings of Hossain et al. (2011) for Flacourtia jangomas stem cuttings applying IBA using similar type of plant propagator and almost similar environmental conditions.

Table 1. Effect of IBA concentrations on survival, cutling height and leaf number of Flacourtia indica three months after transferring into polyethylene bags

\begin{tabular}{lccccc}
\hline \multirow{2}{*}{ Variable } & \multicolumn{5}{c}{ Treatment } \\
\cline { 2 - 5 } & Control & $0.2 \%$ IBA & $0.4 \%$ IBA & $0.8 \%$ IBA & \\
\hline $\begin{array}{l}\text { Survival } \\
\text { percentage (\%) }\end{array}$ & $60.75 \pm 7.72$ & $71 \pm 7.18$ & $84.5 \pm 5.72$ & $63 \pm 7.63$ & 0.000 \\
\hline $\begin{array}{l}\text { Cutling height } \\
(\mathrm{cm})\end{array}$ & $31.6 \pm 7.35$ & $43.95 \pm 7.84$ & $48.48 \pm 7.90$ & $31.80 \pm 7.36$ & 0.000 \\
\hline Leaf number & $32 \pm 7.38$ & $47.5 \pm 7.90$ & $50.75 \pm 7.91$ & $35.5 \pm 7.57$ & 0.000 \\
\hline
\end{tabular}

\section{Conclusion}

F. indica is one of the most important highly nutritious and valuable fruit species in Bangladesh that needs to be domesticated in homesteads for many reasons. Although propagation by seed is the prime method of plant multiplication, inadequacy of seeds as well as inadequacy of quality seeds is the major constraint that hampers plantation programs in the tropics. Flacourtia indica is also a mangrove forest originated wild fruit species of Bangladesh which never been cultivated in homesteads but were growing naturally. Due to increased population and shrinkage of coastal mangrove forest area the species has now reached almost an endangered situation. Due to scarcity of fruits or seeds vegetative propagation through stem cutting can be a better and helpful method of plant multiplication. The application of vegetative propagation in domestication of $F$. indica in homesteads of coastal areas of Bangladesh will ensure the production of uniform planting materials with desirable fruit characteristics (taste, seize, color), dis- 
ease resistance and tree morphology. In the present study, F. indica was found amenable for clonal propagation through stem cutting with application of rooting hormone IBA using low-cost non-mist propagator. The results showed that the highest rooting percentage (100) and maximum root number (8) of F. indica stem cuttings were obtained from the cuttings treated with $0.4 \%$ IBA followed by $0.2 \%$ IBA where as the longest root length $(8.99 \mathrm{~cm})$ was recorded with $0.2 \%$ IBA followed by $0.4 \%$ IBA. Considering both rooting percentage and root number, $0.4 \%$ IBA treatment of stem cuttings may be recommended for mass production of quality planting stocks for domestication of the species in homesteads or in fruit orchards.

The findings of this study are pertinent to efforts towards indigenous wild fruit domestication. Clonal propagation through stem cutting might be one of the effective methods of vegetative propagation. For better performance in rooting, stock plant orchards should be established and serial propagation should be conducted to get more juvenile plant material for large scale multiplication of $F$. indica to ensure food security in natural disasters.

\section{References}

Abdullah, A.T.M., M.A. Hossain and M.K. Bhuiyan, (2005). Propagation of Latkan (Baccaurea sapida Muell. Arg.) by Mature Stem Cutting. Research Journal of Biological Sciences, 1(2):129134.

Booth, T.H. and J.V. Turnbull, (1994). Domestication of lesser-known tropical tree species: the Australian experience.
In Tropical Tree: The potential for Domestication and Rebuilding of Forest Resources, Eds., Leakey, R. R. B. and Newton, A. C., HMSO, 189-193.

Das, D.K., (1987). Edible fruits of Bangladesh, Bulletin 3, Plant Taxonomy Series, Bangladesh Forest Research Institute, Chittagong. pp. 19.

Dias, L.R.M.S., E.T.H. Fronco and C.A. Dias, (1999). Rooting of stem cuttings of different diameters of Platanusacerifolia (Alton) Willdenow. Ciencia Florestal, 9(2): 127- 136.

FAO, (1992). Forests, Trees and Food. FAO, Rome. pp. 26.

Hassig, B.E., (1983). The rooting stimulus in pine cuttings, Combined Proc. international plant propagators society, 32 : 625-638.

Hossain, M.A., (1999). Rooting Ability of Cuttings as Influenced by Preconditioning of Stockplants to Light, MS Thesis, Institute of Forestry and Environmental Sciences, University of Chittagong, Bangladesh. pp. 80.

Hossain, M.A., M.M. Rahman and M. Kamaluddin, (2002). Rooting Ability of Cuttings as Influenced by Etiolation of Stockplants and Auxin. SUST Studies, 4(1):55-65.

Hossain, M.A., M.A. Islam and M.M. Hossain, (2004). Rooting Ability of Cuttings of Swietenia macrophylla King and Chukrasiavelutina Wight et Arn. as Influenced by Exogenous Hormone. International Journal of Agriculture and Biology, 6 (3): 560-564.

Hossain, M.A., M. Sen, M.I.U. Jewel and M.A., Kabir 2011. Propagation of Fla- 
coutia jangomas: an approach towards the domestication of a wild fruit species in Bangladesh, Dendrobiology 65:63-71.

Kamaluddin, M., (1996). Clonal propagation of Eucalyptus and Acacia hybrid by stem cuttings, Research report, Institute of Forestry and Environmental Sciences, University of Chittagong, Bangladesh.

Kamaluddin, M. and M. Ali, (1996). Effect of leaf area and auxin on rooting and growth of rooted stem cuttings of neem. New Forests, 12: 11-18.

Kamaluddin, M, M.E. Miah and S. Pandit, (1998). Propagation of Chickrassia velutina by cutting: response to applied auxin and shoot production. Malaysian Forester, 61: 92-100.

Kamluddin, M., M. Ali and M.K. Bhuiyan, (1996). Effect of auxin on rooting and growth of stecklings of jackfruit (Artocarpus heterophyllus). Chittagong University Studies, Part II: Science, 20(1):71-75.

Kirtikar, K.R. and B.D. Basu, (1998). Indian Medicinal Plants. Ed 3rd, Vol II, Singh and MP Singh Publications, India, pp. 220.

Leakey, R.R.B., J.F. Mesen, Z. Tchoundjeu,
K.A. Longman, J.Mc.P. Dick, A. Newton, A. Matin, J. Grace, R.C. Munro and P.N. Muthoka, (1990). Low technology techniques for the vegetative propagation of tropical trees. Commonwealth Forestry Review, 69: 247-257.

Nahar and M.M. Rahman, (1990). Analysis of carbohydrates in seven edible fruits of Bangladesh. Journal of the Science of Food and Agriculture, 51(2):185192.

Nazneen, M., M.A. Mazid, J.K. Kundu, S.C. Bachar, M.A. Rashid and B.K. Datta, (2002). Protective effects of Flacourtia indica aerial parts extracts against paracetamol induced hepatotoxiciy in rats. J Biol Sci.,11(2):183-187.

Rosa, L. and S. Dos, (1997). Promotion of rooting in stems cuttings of tschi-branco (Sclerolobium paniculatum Vogel) by application of different concentrations of indole-3 -butyric acid, Boletim da Faculdade de Ciencies Agraries do Para. 28:81 -91.

Ulfa, F., E.L. Sengin, Baharuddin, S. A. Syaiful, N. R. Sennang, Rafiuddin, Nurfaida and Ifayanti, (2013). Potential of Plant Extracts as Growth Exogenous Regulators of Potato Seeds, Int. J. Agr. Syst, 1(2):98-103. 